\title{
LA OTRA IDENTIDAD URBANA: MIEDO, FRAGILIDAD Y DERROTA EN LOS DISCURSOS POPULARES SOBRE LA CIUDAD*
}

\author{
Raúl González González \\ Universidad de Oviedo \\ raull@telecable.es
}

\section{Resumen}

El artículo propone una indagación en torno al papel jugado por el miedo como categoría política e ideológica en las sociedades urbanas bajomedievales. A partir de ejemplos tomados del norte de la Corona de Castilla, se plantea la existencia de una conciencia temerosa acerca de la fragilidad de la comunidad cívica, la cual subyace a los discursos antinobiliarios. El contraste de esta identidad basada en el miedo con el discurso de la honra cívica propio de las oligarquías de la etapa del Regimiento plantea la necesidad de abordar el estudio de la identidad urbana desde una perspectiva diacrónica y menos monolítica, capaz de incorporar la experiencia de grupos sociales diversos.

\section{Palabras clave}

Historia urbana, identidad, miedo, culturas políticas, ideología.

\begin{abstract}
This paper proposes an inquiry into the role played by fear as a political and ideological category in late medieval urban societies. Using examples taken from Northern Castile, it suggests the existence of a fearful awareness of the fragility of the civic community which underlies discourses against nobility. The contrast of this identity based on fear with the discourse of civic honour which was cha-

* Este trabajo se ha desarrollado en el marco de una beca predoctoral del programa "Severo Ochoa" (ref. BPII-09I), financiada por el Gobierno del Principado de Asturias a través de la FICYT. Además, se inscribe en el Proyecto de Investigación financiado por el Ministerio de Economía y Competitividad "Poder, sociedad y fiscalidad en el entorno geográfico de la Cornisa Cantábrica en el tránsito del Medievo a la Modernidad”, HAR2oII-27oI6-Co2-oI, con sede en la UPV/EHU, el cual forma parte del Proyecto Coordinado HAR2OII-270I6-Co2-oo junto con el Proyecto de Investigación HAR2OII-270I6-Co2-02 de la Universidad de Valladolid, así como participa en la Red "Arca Comunis". Además, el presente texto resultó elegido co-ganador del XV Premio Medievalismo de la Sociedad Espańola de Estudios Medievales en febrero de 2015.
\end{abstract}


racteristic of the oligarchies of the period of the Regimiento lays out the need to address the study of urban identity from a diachronic and less monolithic perspective, capable of incorporating the experience of various social groups.

\section{Keywords}

Urban history, identity, fear, political cultures, ideology.

\section{A MANERA DE INTRODUCCIÓN: NOTICIA DE UN DESENCANTO}

\section{Cuerpos ausentes}

En esas encrucijadas identitarias propias de quienes necesitan justificar permanentemente su mera existencia, ${ }^{\mathrm{I}}$ no es infrecuente que los medievalistas traten de responder al interrogante de por qué y para qué estudiar la Edad Media. ${ }^{2}$ Sin embargo, hay otra pregunta que, siendo aún más importante, raramente se formula: ¿en qué condiciones estudiarla? Un rasgo diferencial que siempre me ha sorprendido del medievalismo hispano es su habilidad para esconder la tramoya del trabajo investigador, como si los libros y los artículos fuesen meras segrega-

' Un claro indicio de lo bajo que hemos caído como civilización es el hecho de que haya comenzado a surgir la necesidad de lo que podríamos denominar "libros de autoayuda para gente de letras" escritos por científicos. Véase por ejemplo el curioso enfoque que el diario digital El Confidencial ofreció sobre el último libro del biólogo Edward O. Wilson, en una noticia del I7 de noviembre de 2014 cuyo titular — "Un científico explica por qué importan más las humanidades que la ciencia”- no puede ser más significativo (Barnés, 20I4).

2 Ante la vieja pregunta de para qué sirve la Historia, que ya Marc Bloch planteaba en boca de un niño al inicio de su Introducción a la Historia (Bloch, 1952, p. 9) - y que, por cierto, deja sin responder, aunque el hecho de que la obra esté inacabada impide saber si esa elocuente omisión es voluntaria-, nuestra época funesta sólo parece ofrecer respuestas que rara vez se salen del cliché («Los pueblos que no conocen su Historia están condenados a repetirla») o la justificación en términos de rentabilidad económica (que tan bien enlaza con esa nueva religión del "Patrimonio"). También parecen sobrevivir aún algunos historiadores optimistas que todavía creen que los frutos de su labor investigadora, recogidos en forma de libros y artículos que nadie lee fuera del estrecho círculo de especialistas, pueden funcionar como herramientas de transformación social. Alguien lo llamaría delirio megalómano, pero quizás no sean más que añoranzas de aquella época en la que el historiador comprometido, probablemente no más leído que su homólogo actual, se sabía al menos dignificado por su contribución a la causa. Con todo, es justo reconocer que es muy posible que los nuevos vientos de refuerzo del nacionalismo y la xenofobia que recorren la Europa actual ofrezcan a quien lo desee la oportunidad de recuperar con todo ardor esa vieja militancia del homme de lettres al servicio de su Estado-nación, aunque hace ya tiempo que escritores y periodistas dejaron claro que los historiadores somos absolutamente prescindibles en tal empresa. 
ciones de una suerte de espíritus puros que no encuentran más limitaciones o alicientes a su labor que aquéllos de orden estrictamente intelectual. ${ }^{3}$

La carencia de estudios de los que poder decir, parafraseando las palabras de Cervantes sobre el Tirant, "aquí comen los medievalistas, y duermen y mueren en sus camas, y hacen testamento antes de su muerte, con estas cosas de que todos los demás libros de este género carecen" (Cervantes, 2004, p. 66), es tan abrumadora como inquietante. A diferencia de lo que ocurre en otras latitudes historiográficas, los medievalistas españoles parecen avergonzados de su condición de entidades corpóreas dotadas de querencias, pasiones e intereses, a partir de los cuales interactúan entre sí y con el medio que las rodea. Hasta el punto de que sería difícil encontrar en el medievalismo español siquiera algo parecido a la evocación que hace Peter Brown de su primera lectura de la Retractatio de HenriIrénée Marrou, mientras pasaba una tarde veraniega del año 1956 a bordo de una chalana sobre el río Cherwell, no lejos de las torres de Oxford. ${ }^{4}$ Y, desde luego, estamos a ańos-luz de ser capaces de producir una obra de auténtica historiografía como Inventing the Middle Ages de Norman Cantor, La historia en migajas de François Dosse o El futuro de un pasado. La Edad Media en el siglo XXI de Alain Guerreau.

${ }^{3}$ Es probable que se trate de una característica extensible al mundo académico español en general, pero lo cierto es que, incluso dentro del propio gremio de los historiadores, nuestros colegas dedicados a otros ámbitos cronológicos ofrecen ejemplos más que interesantes de reflexión sobre las condiciones de la investigación histórica. Piénsese por ejemplo en las obras de Josep Fontana, especialista en Historia Contemporánea (1982 y 200I), o de José Carlos Bermejo Barrera, especialista en Historia Antigua (2009a y 2009b).

${ }^{4}$ Un ańo después, el primer contacto con el otro libro que considera crucial en su decisión de dedicarse al estudio de la Antigüedad Tardía, Aspetti sociali del quarto secolo de Mazzarino, le haría llegar tarde al té de las cuatro en la British School de Roma y ganarse fama de trabajador incansable (Brown, 20II, p. 6).

5 No ha de extrañar entonces que quien más se haya acercado a ese objetivo sea un hispanista inglés, Peter Linehan, con los comentarios desperdigados a lo largo de su History and the Historians of Medieval Spain (Linehan, 1993). Muy significativamente, dentro de la extensa producción de Jaume Aurell, medievalista de formación que se ha forjado una carrera investigadora centrada fundamentalmente en la historiografía, los trabajos sobre el medievalismo español, aun siendo de gran interés, ocupan una proporción muy modesta (Aurell, 2005, 2006 y 2008). 
Lo más curioso es que esta especie de miedo a reconocer la presencia del sujeto investigador parece ser una novedad del medievalismo hispano de las últimas décadas con respecto a las generaciones precedentes, como conoce cualquiera que esté mínimamente familiarizado por ejemplo con la obra de Sánchez-Albornoz, cuyos chascarrillos sobre enemistades personales entre investigadores o sobre los combates contra los feroces guardianes de los archivos eclesiásticos contrastan tanto con el habitual tono aséptico de los estudios recientes que no sólo siguen citándose como ejemplo, sino que de hecho algún joven investigador poco avisado podría concluir ingenuamente que se trata de realidades propias del pasado y completamente ajenas al quehacer cotidiano del medievalista actual. Merecería la pena detenerse a analizar cómo, cuándo y, sobre todo, por qué motivos tuvo lugar ese curioso proceso de despersonalización que dio paso a la ilusión de objetivismo

${ }^{6}$ Aunque abandonó los estudios medievales tras la destrucción de su archivo personal durante la Guerra Civil, Ramón Carande es también un buen ejemplo de historiador de la misma generación y nada reacio a desvelar las intimidades de su trayectoria académica e investigadora. Baste recordar su obra memorialista (Carande, I98I, 1982 y 1989). Curiosamente, el medievalismo hispano de las últimas décadas se diría también fascinado por la transparencia de esa generación de historiadores formados antes de la Guerra Civil, que sí han merecido un cierto tratamiento historiográfico $(\mathrm{Ca}$ tedráticos, I993; Ruiz de la Peña Solar, 2009; Ladero Quesada, 201I). Es terriblemente significativo que todavía a la altura del año 2000 (fecha en que fue publicado el número correspondiente a 1998), cuando la Revista de Historia Jerónimo Zurita, 73 (1998) ofreció con su monográfico "Historiadores de la España medieval y moderna" uno de los pocos intentos serios por presentar un panorama historiográfico del medievalismo hispano del siglo $\mathrm{xx}$, se haya centrado precisamente en figuras pertenecientes a la generación de la pre-guerra o, como mucho, la inmediata posguerra. Como si, atenazados por una extraña maldición inherente a su oficio, los historiadores sólo supiesen ser elocuentes al hablar del pasado. 
que recorre los estudios medievales hispanos de las últimas décadas, ${ }^{7}$ pero no es

${ }^{7}$ No sería justo ignorar que existen algunos tímidos ejemplos aislados en los que efectivamente los medievalistas se reconocen como individuos que trabajan en un determinado contexto ideológico, social, profesional y personal. En este sentido destaca la labor del profesor García de Cortázar, probablemente la única figura que ha dedicado específicamente repetidos ensayos historiográficos no ya a las generaciones pasadas, sino al pasado reciente y la actualidad del medievalismo espańol (por señalar uno de los más recientes: García de Cortázar, 2009); además, ha expuesto las coordenadas de su propia trayectoria, bien en forma de entrevista (Díaz de Durana y Ortiz de Urbina, 2008), bien en forma de conferencia, como la pronunciada el 2I de febrero de 2008 en el Instituto de Historia del CSIC de Madrid dentro del seminario "Vida y cultura: reflexiones egohistóricas" y disponible on-line (García de Cortázar, 2008). Pueden señalarse además, entre otros, la contextualización historiográfica que de su propia carrera y de las Semanas de Estudios Medievales de Estella ofrece Martín Duque (1999), la reflexión que hace acerca de su propio recorrido académico RuizDomènec (20I4), el artículo panorámico de Navarro (2008), las páginas con las que Juan Antonio Bonachía abre el número monográfico que la revista Studia Historica. Historia Medieval dedicó al tema "Poder y fiscalidad en la Edad Media hispánica", en las cuales sitúa los estudios fiscales en el marco político de nuestra época de hegemonía neoliberal y desmantelamiento del Estado de bienestar (Bonachía Hernando, 20I2), o las referencias dispersas, escuetas y a menudo convencionales que puedan espigarse en la caterva de misceláneas-homenaje al uso. Dentro ya del campo de la impostura más descarada, no puede dejar de citarse la introducción al libro enormemente influyente que Barbero y Vigil dedicaron a los orígenes del feudalismo (1978), en la que ambos autores pretenden presentarse como una suerte de revolucionarios marginales en vísperas de ser represaliados por sus ideas. En la p. 20 aluden a cómo su postura renovadora "no favorecerá nuestro futuro profesional", aseverando que "después de cuarenta años de respeto al principio de autoridad, en los que no ha existido una crítica propiamente dicha, teníamos el deber de utilizar la mayor libertad de expresión que ahora existe, aun conociendo las consecuencias poco favorables que esto puede acarrearnos". Sin duda, un indicio cierto del lastre que la obra supondría a su "futuro profesional" fue que apenas 5 años después de su publicación Barbero obtuviese la Cátedra de Historia Medieval en sede tan periférica como la Universidad Complutense de Madrid (Vigil había ejercido ya desde 1965 la Cátedra de Historia Antigua de la Universidad de Granada, obteniendo el traslado en 1970 a una institución tan ajena a los centros de poder de la academia hispana como la Universidad de Salamanca). Además, está fuera de toda duda que por ejemplo el profesor Barbero se ajustaba al perfil clásico del represaliado por la dictadura: madrileño, de buena familia (era hijo de un general y una aristócrata), estudiante del colegio del Pilar, licenciado por la Universidad Central y profesor en ella desde fecha tan proclive al aperturismo como 1959; mientras que la "autoridad" cuya obra pretende atacar el libro citado, y que no es otra que Claudio Sánchez-Albornoz, reúne todas las características de un eximio representante de las élites del franquismo: madrileńo de orígenes abulenses, de buena familia de terratenientes y caciques, estudiante en el colegio de los Escolapios de Madrid, licenciado también por la Central y catedrático en ella desde 1920 (fue apartado de la cátedra en 1939), diputado por Ávila como miembro de Acción Republicana e Izquierda Republicana (I93I-I936), ministro de Estado en 1933, vicepresidente de las Cortes en 1936 y presidente del gobierno de la República en el exilio en los años I962-I97I (datos biográficos de los tres autores tomados de Peiró Martín y Pasamar Alzuria, 2002, s.v. Barbero de Aguilera, Abilio; Sánchez Albornoz y Menduiña, Claudio; y Vigil Pascual, Marcelo). El caso, que habrá de quedar registrado en los anales de la historia de la infamia, es tan representativo de la exitosa fabricación de una memoria oficial que permitió consolidar el mandarinato de las viejas familias de la dictadura, presentando a sus retoños como feroces antifranquistas 
éste el lugar más apropiado para ello. ${ }^{8}$

\section{Cuerpos derrotados}

Repito, por tanto, la pregunta inicial: ¿en qué condiciones estudiar la Edad Media? En este caso, la manera más honesta y coherente de responder sería posiblemente intentar explicar la situación académica y profesional de quien escribe estas líneas. Pero como las normas del concurso 9 requieren lógicamente del anonimato, evitaré las alusiones personales y trataré de adoptar una voz, digamos, generacional. Y, dado que este premio va destinado específicamente a jóvenes investigadores, quizá no se trate de una perspectiva del todo inoportuna.

Dentro del medievalismo espańol, probablemente nadie experimente mayor contradicción entre la aparente necesidad de adoptar un discurso neutro e impersonal y las acuciantes presiones de la realidad circundante que los investigadores noveles. Los recortes en el gasto público dedicado a la educación superior y la investigación, el sometimiento constante a evaluaciones formales cuyos estándares rara vez se ajustan a lo esperable o deseable en nuestra disciplina, la autoexplotación disfrazada de flexibilidad horaria o de cultivo de una vocación, una política científica errática y empeñada en batir periódicamente sus propios récords de estulticia, la saturación de las revistas de calidad y la consiguiente dilatación de los plazos de publicación, la ausencia de un mercado editorial propiamente dicho, la monstruosa hipertrofia de la burocracia o la persistencia de la endogamia y las banderías son males que afectan en mayor o menor medida al conjunto del gremio, sin duda. Pero cuando van además unidos a la precariedad económica y laboral, que para los jóvenes investigadores es sistémica (lo es ahora en la "crisis" y lo era ya en la supuesta época de bonanza previa), dejan de ser signos más o menos irritantes de la decadencia de un oficio que por el momento al menos sigue dándole a uno de comer y se convierten en obstáculos insalvables para desarrollar una carrera profesional digna de ese nombre.

mientras condenaba al ostracismo o el oprobio a los viejos republicanos, que merecería ser incluido en cualquier estudio sobre el tardofranquismo y la Transición española.

${ }_{8}$ Baste apuntar que el proceso podría no haber sido del todo ajeno a ese "agujero negro" del que habla Morán (1999).

9 Como se ha señalado en la primera nota al pie, el texto fue presentado a concurso para un premio de jóvenes medievalistas; de ahí algunas de sus peculiaridades. 
Sean conscientes de ello con mayor o menor intensidad, tal es el marco de precariedad, acoso e incertidumbre en el que se desarrolla desde hace ya demasiados años la actividad académica e intelectual de la práctica totalidad de los jóvenes medievalistas españoles (de los jóvenes investigadores españoles en general). Una Terre Gaste cuyo horizonte aparece teñido por la vieja sombra del exilio.

Como resultado, la condición natural del joven medievalista es una agotadora mezcla de pasión y desencanto: sin perder nunca esa energía que nace del amor por un oficio hermoso, siente cómo le va habitando progresivamente la desencantada lucidez de quien sabe que ningún esfuerzo le librará de ser empujado al abismo. Esperar que no traslade algo de todo eso a su propia investigación sería, supongo, pedirle demasiado.

PLANTEAMIENTO DEL TEMA

Quizá uno de los efectos más esperables y evidentes de ese desencanto sea una cierta insatisfacción con los cauces de investigación vigentes en el medievalismo hispano, tan propenso a las inercias, la cual genera la necesidad de explorar nuevos temas y, sobre todo, de abordarlos a partir de nuevos enfoques. Siguiendo un patrón clásico en la historiografía española (que, buena discípula de la tradición francesa, lleva apelando a la "renovación" y las "nuevas interpretaciones" desde hace al menos 40 o 50 años), los jóvenes medievalistas buscan inspiración más allá de nuestras fronteras y abrevan en las siempre refrescantes aguas del extranjero.

No es otro el caso de quien escribe estas líneas, salvo quizá por una particularidad: debo confesar que la inspiración foránea que alentó las inquietudes que dieron pie al presente trabajo no provino de la lectura de investigadores contemporáneos, sino de dos obras medievales: la Cronica delle cose occorrenti né tempi suoi del florentino Dino Compagni, que abarca en su narración la historia política de Florencia entre los años I280-1312 (Compagni, 2013); y el anónimo Journal d'un bourgeois de Paris, de la primera mitad del siglo xv (Beaune, 1990). ${ }^{\text {IO }}$ Para quien como yo se había formado en la tradición del medievalismo castellano, ambas crónicas parecían sugerir la posibilidad de abordar el mundo urbano de la Baja Edad Media con una mirada un tanto diferente a la habitual entre los investigadores dedicados a las ciudades de la Corona de Castilla, donde la tipología

Io La fuente ha merecido recientemente dos estudios en castellano (Mitre Fernández, 20II; González González, 2014). 
documental disponible obliga a hacer un tipo de historia política urbana quizá demasiado mediatizada por los avatares de la monarquía y la alta nobleza."

Pero hay algo más. Como es bien sabido, una de las escasas alegrías que nos reserva la Administración a los becarios predoctorales es la posibilidad de jugar a creernos profesores durante no más de 60 horas por curso académico, en una suerte de remedo burocrático de aquellas viejas festividades carnavalescas del "obispillo" o el "rey de la faba" (Lacarra y Cacho Blecua, 20I2, pp. I76-I79). Bajo el amparo de ese marco legal tuve la fortuna de impartir en marzo de 2014 una práctica titulada "Construir la política: los comuni de la Italia medieval", en el transcurso de la cual planteé a los alumnos del $2^{\circ}$ curso del Grado en Historia de la Universidad de Oviedo la pregunta de por qué creían que podía existir un cierto empeño en buena parte de la historiografía de las últimas décadas, desde variados cotos académicos y corrientes ideológicas muy diversas, por negar prácticamente cualquier carácter democrático (no necesariamente en el sentido moderno del término) a los regímenes urbanos del Popolo establecidos en la Italia del siglo XIII. ${ }^{\text {I2 }}$ Hubo varias respuestas inteligentes, pero la de una alumna, Martina Méndez Fernández, me pareció de tal elegancia que aún sigue haciéndome reflexionar. Venía a decir algo así: "porque atribuirles algún atisbo democrático obligaría a reconocer que la democracia puede fracasar”.

¿Puede fracasar la democracia? La pregunta, en principio, parece más propia del ciudadano que del medievalista. Traducida en términos históricos, podríamos reformularla como ¿pueden fracasar las comunidades políticas urbanas?, ¿̨uáles son los peligros que las amenazan?, ¿existió entre los habitantes de las ciudades

${ }^{\text {II }}$ Lejos de mí no obstante la intención de caer en el defecto contrario y proponer una historia política urbana ajena a la relación de las ciudades con los poderes monárquico y nobiliario, que tanta influencia ejercieron sobre las comunidades urbanas de la Castilla bajomedieval. De hecho, precisamente en los últimos años esta cuestión, que había adquirido un cierto sabor clásico, está siendo replanteada con enorme acierto e interés dentro del medievalismo castellano por estudios que aportan enfoques renovadores, en consonancia con los nuevos planteamientos de la historia del poder (Díaz de Durana Ortiz de Urbina y Fernández de Larrea y Rojas, 2008, 2013; Jara Fuente, 2010, 2011a, 20I3a, 20I3b; Montero Málaga, 20I2a; Nieto Soria, 2000-2002; Pelaz Flores, 20I2, 2013a, 2013b). Por su parte, el medievalismo francés ha ofrecido recientemente una obra colectiva que reivindica la importancia de la presencia nobiliaria en la ciudad, tema tradicionalmente menos trabajado por la historiografía gala (Dutour, 20I0).

${ }^{12}$ Hace no mucho apareció una monografía especialmente sugerente sobre esta singular experiencia política (Poloni, 20IO), cuya autora ofrece además agudas reflexiones sobre el tema y su tratamiento historiográfico en dos artículos de gran interés (Poloni, 2005 y 20I2). Sobre el problema más general de la relación entre los comuni de la Italia medieval y la democracia pueden consultarse, por ejemplo, las diferentes perspectivas ofrecidas por Skinner (I995) o Artifoni (2006). 
medievales algún tipo de conciencia de esa fragilidad? El presente trabajo no será, en buena medida, sino un intento de adentrarme, con más temor que prudencia, por esa peligrosa senda interpretativa.

\section{UNA IDENTIDAD URBANA SOTERRADA}

En el taller de todo historiador dedicado al estudio de las categorías socioculturales debería haber una inscripción bien visible con un mandamiento que permanentemente le recordara en tono escueto y cortante las fronteras del oficio: No reificarás. Apenas llevamos unos años hablando de identidad urbana, y se diría que ya la hemos convertido en uno de esos términos-fetiche que sirven de coartada para incurrir en generalizaciones abusivas, evitar la discriminación social de los conceptos y dejarse llevar por personificaciones que empiezan siendo supuestas metáforas y acaban funcionando como nudo argumental de la exposición (por ejemplo, esas ciudades taumatúrgicas que pueblan tantos estudios en los que se nos anima a creer que "hacen", "dicen" e incluso "piensan").

Por decirlo brevemente: hasta el momento, los medievalistas castellanos no nos hemos ocupado tanto de la identidad urbana — que no existe en esa forma de entidad monolítica y unánime- como de una de las identidades urbanas posibles: ${ }^{\mathrm{I3}}$ la de las oligarquías que controlaban los resortes del poder en la etapa

${ }^{13}$ Ya Del Val Valdivieso (2006) señalaba que el principio de identidad urbana común era interpretado de forma diferente por gobernantes y gobernados, en función de unos intereses contrapuestos; y Solórzano Telechea (2007) diferenciaba entre una "identidad cívica" propia de la oligarquía urbana y fundamentada en las nociones de antigüedad, honra y privilegio y una "identidad civil" del Común, basada en principios como equidad, participación o bien común. Además, el espléndido artículo de Rafael Oliva sobre el motivo del rey prisionero (Oliva Herrer, 20II) se inicia con unas consideraciones acerca de la noción de identidad política que precisamente tratan de encauzar el debate dentro de unos términos razonables. Así por ejemplo, en la p. 363 se afirma que "tal como ha demostrado de manera convincente la crítica postcolonial, las identidades no son exhaustivas, bien se trate de identidades familiares, comunitarias, de clase y, por supuesto, de identidades políticas. Los individuos participan de identidades diferentes, y el tipo de argumentos y recursos culturales que movilizan puede variar y de hecho lo hace en contextos diferentes", y en la p. 366 se ofrece la siguiente acepción, que suscribo por parecerme especialmente fértil para el investigador, al hacer hincapié en el carácter dinámico y consensual de la identidad: "la construcción de identidades políticas tiene que ver con la asunción de determinados referentes que posibilitan la constitución de una estructura compartida para la comprensión de determinadas relaciones". También Montero Málaga (20I2b) señala algunas carencias en el tratamiento habitual de la identidad urbana en el medievalismo, como cuando al reseñar los estudios sobre el significado de las fiestas o los juegos para el desarrollo del honor y la honra urbana, afirma que "la mayoría de estos trabajos se han 
del Regimiento y que por supuesto se encargaron de proyectar $s u$ imagen identitaria de la ciudad en las fuentes que mayoritariamente utilizamos para historiar el mundo urbano de la Corona de Castilla en los siglos XV-XvI: actas concejiles y documentación municipal en general, memoriales, cartas, peticiones de Cortes, crónicas, descripciones y tratados... Es cierto que no es infrecuente que en las introducciones a los trabajos sobre el tema se formulen algunas precauciones acerca de este carácter socialmente marcado de la identidad urbana que será objeto de análisis, pero en la práctica lo más habitual es que tales objeciones se disuelvan en cuanto nos adentramos en el cuerpo del estudio y que en adelante nos encontremos con alusiones aparentemente desproblematizadas a "la identidad urbana" o "la ciudad" tout court.

Como han venido señalando diversos estudios a partir del trabajo seminal y ya devenido clásico del profesor Bonachía (1996), en el registro documental que conservamos de esa identidad urbana oligárquica parece claro que la noción de "honra" juega un papel fundamental. Hasta el punto de que podríamos decir, sin exagerar demasiado, que en ese tipo de discursos se nos ofrece toda una retórica de la ciudad basada en el orgullo. Una retórica que hace hincapié en la grandeza, la nobleza y el honor, pero que promueve además una determinada praxis de gobierno interesada en el fomento de la obra pública, la salubridad y el embellecimiento urbano (Álvarez Carballo, 20Io; Álvarez Fernández, 2009, pp. 387-423; Álvarez Fernández, 20I3; Álvarez Fernández, 20I4, pp. 25-27; Bonachía Hernando, 1996, pp. 194-200; Bonachía Hernando, 2013; García Fernández, 2004, pp. I42-I43; Majo Tomé, 20I2, pp. I557-I559; Pelaz Flores, 2010). Las autoridades municipales construyen de este modo un discurso del orgullo ciudadano que tiene consecuencias muy concretas en la gestión política cotidiana, y que probablemente alcanza su mayor eficacia propagandística a través de su traducción en una experiencia ritual colectiva. En ella, la oligarquía consigue plantear, transmi-

limitado a estudiar cómo estos acontecimientos sirven para generar una identidad colectiva con la que se identifican todos los vecinos de la ciudad frente a los otros, los agentes externos a ella. Estas interpretaciones, aunque correctas, no profundizan en el estudio de estos eventos como mecanismos generadores no sólo de una identidad externa sino también interna, cuestión que debe ser tenida en cuenta para futuras investigaciones" (p. 137). Sobre la problemática historiográfica y conceptual de la noción de identidad debe consultarse, además, Jara Fuente (20II), que es la introducción a un número monográfico dedicado a "La definición de la identidad urbana. Vocabulario político y grupos sociales en Castilla y Aragón en la Baja Edad Media"; así como los trabajos reunidos en Jara Fuente (20I3c). Sin duda el profesor Jara Fuente es el medievalista castellano que más atención ha dedicado a las cuestiones relativas a la identidad urbana en sus estudios, por lo demás densos y numerosos, que no cabe citar aquí exhaustivamente. 
tir y recrear un imaginario de armonía social, unidad y consenso en el que, en una suerte de "onanismo social" à la Durkheim, la comunidad urbana se adora a sí misma a través de toda una serie de celebraciones que pueblan el calendario cívico (fiestas, ceremonias litúrgicas, procesiones...) ${ }^{\mathrm{I} 4}$ y parece hacer gala de una estupenda unanimidad. ${ }^{\text {Is }}$

Estos fenómenos son ya relativamente bien conocidos, y casi podría decirse que monopolizan el universo semántico de la noción de "identidad urbana" en el medievalismo castellano de los últimos ańos. Sin embargo, creo que hay indicios suficientes como para rastrear otra forma de identidad urbana, soterrada en nuestras fuentes, la cual habría permitido desarrollar un discurso diferente sobre la ciudad, articulado no ya sobre el orgullo, sino sobre el miedo. Un discurso netamente político en el que la comunidad urbana, lejos de presentársenos como una realidad que, inmutable e imperecedera, pertenece al orden natural de las cosas (según plantearía el imaginario de la honra cívica festiva), aparece caracterizada por su condición de artefacto socialmente construido y como tal coyuntural, frágil y vulnerable.

${ }^{14}$ Si para la Corona de Castilla el trabajo que ha marcado el interés sobre estas cuestiones es sin duda el ya citado del profesor Bonachía (1996), un texto pionero a nivel europeo parece haber sido Pythian-Adams (1972), que aparece repetidamente citado en este tipo de estudios y que desgraciadamente no he podido consultar; algo más tarde aparecería la monografía de Edward Muir sobre Venecia, dedicada fundamentalmente al siglo Xvi (Muir, 198I), y unos años después se publicaba un primer estudio comparativo sobre ciudades toscanas (Ventrone, 1988). Para el caso especialmente rico de las ciudades de Italia y los Países Bajos existe bibliografía reciente de gran interés (Caby, 2008; Crouzet-Pavan, 2008; Lecuppre-Desjardin, 2004; Ventrone, 2007, 2013). Cfr. con dos reflexiones críticas sobre el concepto de "religión cívica" recogidas en el número 27 de la revista Histoire Urbai$n e$, dedicado al tema Religion civique, $X V^{e}$-XVI siècle (Signori, 20IO; Monet, 20Io). Finalmente, merece la pena consultar también el espléndido catálogo de una exposición organizada recientemente por la Galleria dell'Accademia de Florencia, dedicada a los símbolos utilizados en la representación artística de la ciudad (Donato y Parenti, 2013).

${ }^{\text {Is }}$ Ese empeño oligárquico por mostrar una imagen de unanimidad en el culto a la honra cívica es lo que hace que cualquier manifestación de rechazo por parte de los grupos populares hacia cuestiones como el embellecimiento urbano o las celebraciones festivas pueda considerarse una verdadera protesta política. Lo vemos por ejemplo en la villa de Avilés, cuando en 1485 un pescador llamado Pedro Cochelón "dixiera que daría grand quantía de maravedís por que toda la calle de la Rua Nueva fuese quemada" (Cienfuegos Álvarez, I999, pp. IIO-III), siendo precisamente en la plaza de dicha calle donde se había fijado la construcción de la casa de concejo (p. 33); o en Oviedo, cuando en I499 la cofradía de los zapateros se niega a obedecer el tradicional mandato del Regimiento a las cofradías de la ciudad de organizar unos juegos para festejar el día del Corpus, negativa que motivará un pleito que acabará en Chancillería (Fernández San Felices, 2008, pp. 73, 96, I30-I35, I45, I5I-2 y I69; Álvarez Fernández, 20I4, pp. 20-2I, 44 y IIO-II3; A.R.CH.V., Registro de Ejecutorias, caja I47, nº 36). 
La tesis, quizá polémica, que querría plantear aquí, es que esa identidad urbana basada en la imagen de la ciudad como fábrica política que incorpora la posibilidad de su propia destrucción, como espacio de la derrota posible, es una categoría que se originó en el comunitarismo vecinal de la época plenomedieval y a fines de la Edad Media constituyó un rasgo específico del repertorio ideológico de los grupos populares. ${ }^{16}$ De este modo, esa identidad habría funcionado durante siglos como un referente que estaba disponible para ser activado en momentos determinados con el fin de respaldar objetivos políticos concretos, y que podemos detectar por tanto ocasionalmente en los discursos sobre la ciudad. Sobre todo, en los discursos anti-nobiliarios, en los que esa fragilidad y vulnerabilidad de la identidad urbana se presenta de acuerdo con una estrategia retórica que despliega un uso político de las emociones basado en la apelación al miedo.

\section{HACER POLÍTICA DESDE LAS EMOCIONES: EL MIEDO URBANO}

La historia política de las emociones no es un campo demasiado explorado por los medievalistas que trabajan sobre la Corona de Castilla, y aunque ha comenzado a interesar recientemente a los estudiosos de la monarquía (Foronda, 2007 y $2013 \mathrm{a} ;{ }^{17}$ Nieto Soria, 2013), ${ }^{18}$ está prácticamente ausente en los trabajos sobre el

${ }^{16}$ Eso no quiere decir que la identidad basada en el orgullo urbano no formase parte también de su repertorio, aunque llama la atención que incluso cuando los grupos populares acuden a esa forma de identidad, parecen ofrecer un discurso en el que el orgullo no se fundamenta en las cualidades de la ciudad (honor, nobleza, belleza...), sino en las acciones de la comunidad urbana. Puede verse con claridad en la carta que envió la Comunidad de Valladolid al cardenal Adriano en enero de I52I, en pleno conflicto comunero, en la que presenta a las comunidades como sostenes de los reyes frente a la nobleza a lo largo de las luchas civiles del siglo xv (Pérez, 1977, pp. 470-47I; Oliva Herrer, 20II, pp. 367-368). La misma idea aparece un siglo antes en el Journal d'un bourgeois de Paris, cuando en el contexto de la guerra civil entre Armagnacs y Borgońones el anónimo cronista relata una expedición armada de las milicias de París, Ruán y otras ciudades que tuvo lugar en I4I2 contra los Armagnacs, asegurando que éstas, de no haber sido traicionadas por el capitán noble que las dirigía, "eussent nettoyé le royaume de France des faux traîtres en moins d’un an” (Beaune, I990, \$55; González González, 20I4, pp. 354-355). Incluso cuando Compagni (2013) ofrece un elogio aparentemente estereotipado de la ciudad de Florencia (I, 4), se preocupa de añadir a continuación que tales honores habían sido adquiridos por los antiguos ciudadanos "con molta fatica e con lunghissimo tempo" (I, 5).

${ }_{17}$ Ambos estudios aparecen recogidos ahora, aparentemente reelaborados, en Foronda (20I3b), que no he podido consultar.

${ }^{18}$ Agradezco además especialmente las sugerencias que acerca de la política emocional he recibido de Diana Pelaz Flores, que está trabajando sobre el tema. 
mundo urbano. ${ }^{19}$ Sin embargo, una lectura atenta de las fuentes permite constatar que, lejos de constituir un aspecto meramente subjetivo de la vida privada, cuyo estudio no ofrecería mayor interés que cualquier otra de esas ornamentales extravagancias historiográficas, tan fulgurantes como efímeras, a las que nos tuvo acostumbrados durante ańos cierto ensayismo francés, la expresión emocional puede ser utilizada y de hecho se utilizó como una herramienta política de primer orden. ${ }^{20}$ Aquí me ocuparé concretamente del papel jugado por el miedo ${ }^{21}$ en los discursos urbanos de tipo comunitario o popular, a partir de ejemplos tomados del ámbito norteño de la Corona de Castilla.

En primer lugar, hay que recordar el hecho obvio pero fundamental de que en el Derecho castellano de la época el miedo tiene un valor jurídico preciso como causa de nulidad (Foronda, 2007, párrafo 2). Por tanto, la apelación al miedo (o a su ausencia) era una práctica habitual en los pleitos judiciales y los actos jurídicos en general (baste recordar las fórmulas testamentarias que garantizan que el documento se ha otorgado "sin miedo e sin premia"), por lo que, al menos como tecnicismo legal, debía de ser una referencia que formaba parte de la experiencia cotidiana.

Pero cabe señalar además que, en una concepción del mundo en la que la armonía debe presidir las relaciones sociales, la mera expresión del miedo puede suponer un acto político. Desde este punto de vista, decir "tengo miedo" supone reconocer que algo va mal, lo que equivale a formular una crítica que pone en cuestión la legitimidad de la situación social y política vigente en un momento determinado. Ya las Partidas, cuando diferencian entre temor y miedo, señalan

19 Como excepción puede señalarse la interesante perspectiva "políticoafectiva" que aborda el profesor Jara Fuente en uno de sus artículos ya citados (2013a, pp. I33-I4I). A diferencia de lo que ocurre en el medievalismo castellano, en otros ámbitos geográficos hace ya años que se trabaja en esta línea, como demuestran obras como Lecuppre-Desjardin y Van Bruaene (2005) o Boucheron (2013), aunque por desgracia yo no he podido consultar ni una ni otra. Sin embargo, a tenor de las sinopsis y reseñas del libro de Boucheron, parece que en él se trata el miedo político urbano desde una perspectiva bastante afín a la que intento ofrecer en este trabajo.

${ }^{20}$ Foronda (2007, párrafo I), hace el siguiente balance de los aspectos que pueden considerarse asentados en la investigación de los últimos años sobre emociones políticas: "la idea de que las emociones son una construcción y que como tal ésta tiene una cronología específica; que esta construcción enraíza en una realidad social precisa, apuntando pues lo que se suele ya llamar "comunidades emocionales"; y que esta construcción emocional y su puesta en marcha tienen una eficacia especial en términos de comunicación y de acción políticas, una eficacia muy cerca en definitiva de la que pueden tener los rituales, de los que participa la expresión de las emociones”.

${ }^{21}$ Sobre la historia del miedo es imperativo citar la obra pionera de Delumeau (I989), si bien aborda el tema desde una perspectiva bastante diferente de la que trataré de ofrecer aquí. 
que este último "es como desamparamiento" (II.I3.I5; citado en Foronda, 2007, Anejo documental $\mathrm{n}^{\mathrm{o}} 2$ 2). ${ }^{22}$ La idea de que quien tiene miedo está desamparado convierte a esta emoción en un recurso muy eficaz para apelar a un poder superior en busca de protección y justicia, ${ }^{23}$ y en ese sentido podemos decir que se hizo de él un uso generalizado, ${ }^{24}$ pues podía servir a los intereses de cualquier grupo social, desde la alta nobleza (Foronda, 2007, passim) hasta los labradores ${ }^{25}$ o los judíos. ${ }^{26}$

Si de estas consideraciones generales pasamos ya al ámbito específicamente urbano, vemos que en la ciudad la expresión política del miedo aparece fundamentalmente en los casos en los que se desea resaltar la maldad de un enemigo que pertenece a la nobleza. En primer lugar, cuando se trata de plantear la oposición entre la comunidad urbana en su conjunto y un noble presentado como exterior a ella. Lo vemos ya desde comienzos del siglo XIV en Oviedo, cuando el concejo utiliza el miedo a los desmanes nobiliarios para legitimar sendos acuerdos que sella durante la turbulenta minoría de Alfonso XI, por un lado con el caballero Suer del Dado en $1308^{27}$ y por otro con el obispo y cabildo de la ciudad

${ }^{22}$ Esa diferencia entre temor y miedo forma parte de una teorización acerca del poder que no parece haber encontrado ningún eco en el lenguaje común, que a todos los efectos utiliza ambos términos como sinónimos.

${ }^{23}$ Por ejemplo, frente a otro poder intermedio, según un patrón relativamente habitual que aparece diseccionado en un espléndido trabajo del profesor Monsalvo en el que muestra cómo en los enfrentamientos entre las oligarquías urbanas y los pecheros de la villa y tierra los segundos conseguían en ocasiones sus propósitos a través del recurso al poder exterior, fuese éste señorial o regio (Monsalvo Antón, 2003, pp. 475-478).

${ }^{24}$ Baste recordar el tipo documental conocido precisamente como "cartas de amparo".

${ }^{25}$ Los procuradores de la Junta General del Principado de Asturias se quejaban a los reyes en I475 de que "los omes baldíos que biven con algunos cavalleros e fijosdalgo e otras personas del dicho Prinçipado temorisan a los tales vaqueros e labradores e les toman e roban lo que tienen para sus mantenimientos" (Uría Ríu, 20ioa, p. 334).

${ }^{26}$ En 1438 los judíos de Astorga consiguen protección de las autoridades concejiles apelando al miedo que sienten ante el obispo: "que se reçelauan que por quanto por don Sancho de Rojas, obispo de la dicha çibdat fuera mandado que se fuesen benir a çiertas casas que por él le fueron asignadas e çétera que de fecho serían molestados o prendados o fatigados" (Rodríguez López, 2006, p. 195).

27 "Por muchos males et dannos et robos et prisones de nuestros vezinos et quemas que resçebimos de Gonçalo Peláis de Qualla, vassallo del obispo (...) et tememos resçebir daquí endelantre" (Miguel Vigil, I99I, doc. no LXXXIII, p. I28). 
en $1314,{ }^{28}$ y que parecen haber necesitado de algún tipo de justificación al romper con la tradición política previa, basada en la defensa de la autonomía concejil. ${ }^{29}$

Ya en otro contexto, la expresión del miedo que provoca en la población urbana en su conjunto la acción malhechora de un noble sigue vigente a lo largo del siglo xv: lo encontramos por ejemplo formulado de forma explícita cuando en I425 el concejo y habitantes de la ciudad de León apelan al temor ("se reçelan") para conseguir del rey una carta de amparo frente al noble Ramir Nuñez de Guzmán y sus allegados; ${ }^{30}$ o cuando en I49I la justicia de la villa de Avilés tiene miedo de actuar ("non lo osan reclamar") en un extraño caso de robo de cadáver, posiblemente vinculado a prácticas de tipo mágico-folklórico (se creía que el difunto había robado el ajuar de una iglesia, y quienes sustrajeron el cuerpo lo hicieron aparentemente para comprobar si le había crecido la barba "e otras cosas de sennas"), por estar implicada cierta "persona muy enparentada". Por otro lado, además de las formulaciones expresas cabe la posibilidad de hacer también alusiones implícitas al miedo, como parece ser el caso en un memorial antinobiliario de finales del siglo xv que Arsenio Dacosta ha bautizado como la "mini-crónica" de Marquina, cuando nos relata cómo las autoridades concejiles de dicha villa vizcaína tuvieron que reunirse secretamente en I486 para tomar la decisión de emprender la reclamación judicial de sus derechos sobre el patronato

28 "Terresçiendo que algunos inffantes ho ricos omnes vernían a la villa de Ouiedo et ffarían y algunas cosas desaguisadas a desseruiçio de Dios et del Rey et a danno de la villa et de los que y mueran” (Miguel Vigil, I99I, doc no XCVI, pp. I48-I49).

${ }^{29}$ De hecho, el acuerdo de I3I4 con la Iglesia sería expresamente anulado por el rey niño y sus tutores apenas un año después, alegando que a causa de dicha avenencia "el obispo, deán et cabillo sobre dicho oviésedes más poderío en la villa de Oviedo et en la mi çerca et en las puertas della de quanto nunca vsastes" (Miguel Vigil, I99I, doc no XCVIII, pp. I54-I55). Un reciente y documentado estudio de las luchas entre el concejo y el obispo de Oviedo en Ruiz de la Peña Solar y Beltrán Suárez (20II), que puede ampliarse con el riguroso marco comparativo ofrecido en Ruiz de la Peña Solar (2004).

30 "Que por odio e malquerençia que les han que se reçelan dellos e de cada uno dellos que los matarán o ferirán o lesiarán o mandarán ferir o matar o lesiar o tomar algunos de sus bienes o fazer otros males e dannos en sus personas e bienes e cosas, sin razón e sin derecho, por la qual razón dizen que non osan andar salva e seguramente" (Archivo Municipal de León, doc. n 296). Debo agradecer la generosidad de la profesora María del Carmen Rodríguez López, de la Universidad de León, que me ha permitido consultar su transcripción del documento.

${ }_{31}$ "Por quanto diz que queríamos traer cómmo él tenía barba cresçida e otras cosas de sennas, diz que algunos sennores, por ver sy era verdad, secretament lo desenterraron de la dicha yglesia donde está e lo llevaron a otra parte porque non fose sabido; e que Álvaro de Piedra, justiçia de la villa, ha fecho çierta pesquisa sobre lo susodicho e que a fallo de cómmo çiertas personas lo desenterraron e por quel que lo a fecho diz que es persona muy enparentada non lo osan reclamar" (Sanz Fuentes, Álvarez Castrillón y Calleja Puerta, 20II, doc. nº 199, pp. 508-510). 
de la anteiglesia de Jeméin, usurpados por los linajes de Ugarte y Barroeta (Dacosta Martínez, I998, p. I27; Enríquez Fernández, I989, doc. n² 2I).

Sin embargo, el discurso del miedo puede ser utilizado también políticamente contra las propias familias de la nobleza urbana. Por ejemplo, es así como en I488 Pedro de Calderón y Gonzalo de Solórzano, vecinos de de Santander que estaban enfrentados con el poderoso linaje de los Escalante, consiguen que los reyes ordenen al corregidor de Santander y su lugarteniente inhibirse en la causa que Juan de Escalante y sus consortes habían incoado contra ellos. ${ }^{32}$ Además, es bastante significativo el ejemplo de Oviedo, donde en torno a esas mismas fechas está teniendo lugar un enfrentamiento dentro de la élite urbana entre dos facciones que parecen representar también dos culturas políticas diferentes: por un lado, el linaje de los Argüelles, que está tratando de apoderarse del poder municipal a través de las redes clientelares, la violencia y la coacción; por el otro, una serie de vecinos agrupados en torno a la familia del anciano Juan de Oviedo, un personaje de orígenes probablemente humildes que había experimentado un meteórico ascenso social gracias a su integración en el aparato fiscal de la monarquía a mediados del siglo xv, los cuales por el contrario dicen defender los intereses del conjunto de los vecinos y tratan de conducir su lucha por los cauces legales. Pues bien, es precisamente en los testimonios que podemos vincular a la facción de Juan de Oviedo en los que aparece un uso recurrente de la apelación al miedo, como si efectivamente existiese una conexión evidente entre el discurso antinobiliario y la expresión del temor (González González, en prensa).

Por último, merece la pena detenerse en una tercera opción: el uso político del miedo no ya por parte de la comunidad urbana en bloque contra un noble externo o de algún individuo o facción contra determinados linajes de la ciudad, sino de los grupos populares contra la oligarquía concejil en su conjunto. Es lo que encontramos en 1490 en una queja interesantísima planteada a los reyes por el zapatero Benito López, procurador de los pecheros de la ciudad de León, que narra cómo estos sufren agravios constantes por parte de los regidores, quienes pretenden excluirlos completamente de la gestión de los asuntos municipales. ${ }^{33}$ Solicita que los monarcas envíen un pesquisidor para que se informe detalladamente sobre el asunto, y fundamenta su petición precisamente en el miedo,

32 Habían alegado que "commo sus enemygos son muy poderosos e cavdalosos en la dicha vylla, se temen que reçebyresen muerte o lysiones o danno de sus personas, e que non les serya guardada su justiçia mayormente que dis que vos el dicho nuestro corregidor e vuestros tenyente que soys muy sospechosos e muy favorables a sus enemygos" (Solórzano Telechea, I999, doc. nº 37, pp. 66-69).

${ }^{33}$ Reseńa el documento Santamarta Luengos (1993, p. I58). 
alegando que los pecheros "e todo el pueblo menudo" están "temorizados"; ${ }^{34} \mathrm{y}$, de hecho, solicita que se obligue a los regidores a ausentarse de la ciudad mientras se lleve a cabo la pesquisa, pues de otro modo "non se podría libremente sacar nin fazer", en lo que parece una nueva alusión, ahora implícita, al miedo. De hecho, parece haber reforzado la eficacia de su discurso al fundamentarse de nuevo en el temor para solicitar, una vez hecha la petición anterior, una carta regia de amparo para él y los otros procuradores de los pecheros de la ciudad, la cual le es concedida. ${ }^{35}$

La jugada maestra desde el punto de vista discursivo, sin embargo, reside en la primera petición, pues en ella se afirma que los regidores tratan a los pecheros de León "non commo a vezinos e çibdadanos, mas commo sy la dicha çibdad fuese propia suya de los dichos regidores, e ellos fuesen sus vasallos solariegos". Es decir, se está haciendo una equiparación simbólica entre el comportamiento de los regidores y el de los miembros de la alta nobleza, señores de vasallos, con el fin de poder aprovechar las categorías propias del discurso antinobiliario basado en el miedo para plantear una crítica política de gran calado hacia el modelo de poder oligárquico. Opino que lo más sensato es ver en esta idea, además de un poderoso recurso retórico, la expresión de un discurso auténticamente popular, que ha sabido encontrar en esa imagen de los vecinos que son tratados como si fuesen vasallos una fórmula especialmente afortunada, pues condensa en pocas palabras un sentimiento de agravio con el que puede identificarse automáticamente una buena parte de la población urbana y está dotado, por tanto, de una gran eficacia propagandística como núcleo discursivo sobre el que articular una identidad política alternativa a la que propone la oligarquía.

El razonamiento es, en todo caso, mucho más complejo de lo que parece. En particular, hace asomar dos interrogantes: ¿por qué existe la necesidad de acudir al discurso antinobiliario para construir una crítica política, como dejando traslucir una obsesión por la nobleza como categoría esencialmente negativa?, y ¿por qué la queja parece partir del supuesto de una especificidad sociopolítica urbana, basada en la equivalencia ciudadano = libre? En la respuesta a ambas preguntas,

34 A.G.S., R.G.S., I490-VII, f. 298: "están temorizados porque los dichos regidores los prenden o los fazen prender si enbyan algund mensajero o procurador a Nos a procurar lo que les cumple".

${ }^{35}$ A.G.S., R.G.S., I490-VII, f. 30I: "que se teme e reçela que a cabsa de se aver venido a quexar de los dichos regidores los dichos regidores faran o mandaran fazer asy a el commo a los otros procuradores de las colaçiones de la dicha çibdad algunos males o dannos o desaguisados algunos en sus personas e bienes ynjusta e non debydamente en lo qual sy asy oviese de pasar diz que el e los otros procuradores de la dicha çibdad reçibyrian muy grande agravio e danno".

${ }^{36}$ A.G.S., R.G.S., I490-VII, f. 298. 
que obliga a retrotraerse mucho más allá del siglo xv, está la clave de esa identidad urbana soterrada de la que hablábamos en el apartado anterior. Lo analizaremos más adelante.

\section{LA CIUDAD FRÁGIL}

Además de ese miedo, por así decir legalista y retórico, la apelación al cual tiene una eficacia política inmediata, puede rastrearse en la ciudad otro discurso basado en el temor, pero que estaría más bien vinculado con el imaginario colectivo: se trata del miedo que nace de una identidad basada en la conciencia de la propia vulnerabilidad, de la posibilidad de derrota. $\mathrm{Al}$ menos para el ámbito del presente trabajo (los territorios del norte de la Corona de Castilla), esa ansiedad por la aniquilación posible de la ciudad parece proyectarse siempre hacia un enemigo externo a la propia comunidad urbana: concretamente, detectamos un miedo latente a la nobleza como principal agente de esa derrota. ${ }^{37}$

En primer lugar, a través de la destrucción física: lo vemos en el topos del incendio provocado por el noble como castigo a la ciudad que se le resiste, y que aparece por ejemplo muy claramente en el caso de las villas asturianas al menos desde el siglo xIV, como constatamos a través de la importancia que se otorga a la quema de la pobla de Grado por Gonzalo Peláez de Coalla como factor para la constitución de una hermandad entre los concejos de Oviedo y Grado en I309; ${ }^{38}$ o de la persistencia en el recuerdo ovetense del incendio provocado por el conde Enrique de Noreña (futuro Enrique II de Castilla) durante su cerco a la ciudad en I352, desastre que había quedado fijado físicamente en la memoria urbana a través de la toponimia, como pone de relieve una referencia (el "hero de la quema") aún viva en el año I400 (Álvarez Fernández, 2009, pp. I29-I32; Uría Ríu, 2008). Pero el caso más expresivo es el de la villa de Llanes, donde encontramos registrada por el cronista flamenco Laurent Vital en I5I7 una tradición oral según la cual la puebla habría sufrido en tiempos pasados un devastador incendio provocado por un magnate que intentó tomarla, y que parece remitir a los intentos del linaje de los

${ }^{37}$ La fuerza de la ofensiva señorializadora de época Trastámara (Díaz de Durana Ortiz de Urbina y Fernández de Larrea y Rojas, 2013) no habrá sido ajena a esa obsesión.

${ }_{38}$ "Veyendo et entendiendo en conmo Gonçalo Pelaiz de Qualla, por ssi et por sos vassalos (...) ffaziendo a nos los dichos Conçellos muchos males en matando muchos onmes de nuestros vezinos seguros et en quemando la Pobla de Grado et en quemando et robando [otr] os lugares muchos del Rey” (Miguel Vigil, I99I, doc. no XCI, p. I4I; Ruiz de la Peña Solar, 2006, p. 57). 
Quiñones por hacerse con el control de la villa a mediados del siglo xv (Álvarez Carballo, 2013, p. 456). ${ }^{39}$ Encontramos por tanto un patrón que emplea sucesos reales para construir un relato arquetípico capaz de persistir en la memoria colectiva, y que hace un uso ideológico de la ciudad incendiada como símbolo del valor esencialmente destructivo de la nobleza para la comunidad urbana.

Fuera ya del país asturiano, es muy probable que este mismo patrón ideológico sea el que justifique la inclusión en la mencionada "mini-crónica" de Marquina, que narra con gran hostilidad la intervención de los linajes de Barroeta y Ugarte sobre la villa, de una aparente digresión sobre "la primera quema" de la población, que habría tenido lugar en I4II y cuyas causas no se especifican (Enríquez Fernández, 1989, doc. no 21)..$^{40}$ Además, dada esta tradición previa, creo que la vigencia del topos de la villa incendiada como emblema de la opresión nobiliaria podría justificar el extraordinario influjo que tuvo la quema de Medina del Campo el 2I de agosto de 1520 como catalizador de la revuelta comunera. ${ }^{4 \mathrm{I}}$

Pero este imaginario del miedo antinobiliario no se agota con la ansiedad ante el peligro de destrucción física. Al menos para los núcleos realengos sugiere otra posibilidad, no menos inquietante, de destrucción de la comunidad urbana por parte de la nobleza: la aniquilación política, esto es, la sujeción de la ciudad al señorío de un "grande". El miedo a que esto ocurra parece anidar, principalmente, entre los grupos populares. ${ }^{42}$ Así por ejemplo, en Valladolid la comunidad

39 "Por guardar la fidelidad que tenían y tienen a la corona de Castilla, las buenas gentes fueron arruinadas y varias han muerto y la villa [fue] casi reducida a ruinas, sin haber sido los habitantes vencidos por su enemigo, un quidam que, después de la muerte del rey de Castilla, creyó poder robar, tomar y usurpar la villa para sí, aunque a primera vista iba allí con buenas formas (...) Cuando éste conoció que en ningún modo querían condescender, por despecho determinó ir a mano airada y en varios sitios echarles fuego para quemarlos y arruinarlos, como lo hizo; el fuego prendió en varios sitios de la villa y poco después mandó dar un áspero asalto (...) dejaron a las mujeres ocuparse del fuego y los hombres se pusieron todos a defender el asalto, en el cual se comportaron tan valientemente que rechazaron a sus enemigos; pero no fue sin perder en él muchas de sus gentes; y tener gran pérdida y daño que todavía se resentían, pues no estaba rehecha más que la mitad de las casas que por el fuego habían perdido, hallándose vacantes los solares" (Uría Ríu, 2orob, pp. 687-723: el estudio del incendio en pp. 703-713, y el texto del relato en pp. 703-704).

${ }^{40}$ En Dacosta Martínez (1998, p. I26, nota I8), el autor afirma que no cree que la narración del incendio esté descontextualizada y que tiene una hipótesis sobre su relación con el objetivo principal del memorial, si bien no puede detenerse a explicarla.

${ }^{41}$ "El incendio provocó gran indignación en toda Castilla, cuyo resultado fue que estallaran revueltas en muchas ciudades que hasta entonces habían permanecido en calma” (Pérez, 1977, p. I78); "el incendio de Medina del Campo contribuyó, como pocos otros acontecimientos, a extender la adhesión al movimiento comunero por los pueblos y ciudades” (Fernández, 1995, p. 95).

${ }^{42} \mathrm{Y}$ probablemente no les faltaban motivos, pues por ejemplo en Astorga el paso a la condición de concejo de seńorío en 1465 supuso "la anulación del común de vecinos como elemento parti- 
parece haber sido la única fuerza que se opuso decididamente a la injerencia de los grandes nobles en la ciudad durante los enfrentamientos civiles que asolaron el reinado de Enrique IV (Majo Tomé, 20I3, pp. 440-442); y cuando en I5I6-I5I7 el conde de Benavente edifique una nueva casa en la villa será también el común quien transmita a través de las cuadrillas su malestar al respecto ante la pasividad del Regimiento, al considerar que se trataba de una auténtica fortaleza que podría poner en peligro la independencia política de la villa, teniendo en cuenta además la cercanía de las tierras de señorío del conde, en las que éste podría reclutar fácilmente un ejército (Majo Tomé, 2013, pp. 445-446). En León contamos con un ejemplo bastante similar en I5II, cuando el marqués de Astorga pretende comprar al cabildo una casas junto a la muralla, y el regidor Pedro Núnez de Guzmán trata de impedirlo expresando su temor de que eso pueda llevar al marqués a apoderarse de la ciudad. ${ }^{43}$ Conviene recordar que, a pesar de su pertenencia a la oligarquía, este personaje era hermano de Ramir Nuñez de Guzmán, ${ }^{44}$ quien pocos años después sería el líder de los comuneros de León, ${ }^{45}$ por lo que quizá debamos ver en sus palabras un eco de la preocupación popular.

cipativo en la gestión de los intereses comunales y la entrega de todos los instrumentos de poder en manos de una oligarquía aristocrática directa o indirectamente vinculada a la cúspide señorial" (Martín Fuertes, 1987, p. 249).

43 A.G.S., Cámara-Personas, leg. 2-2-I, f. 495: “e por ser ansí las casas en lo más noble e fuerte desta dicha çibdad sytuadas, si la dicha venta pasase sería en grande dapnno e perjuizio de los vezinos e moradores desta çibdad", porque siendo el marqués "persona tan poderosa, e aviendo algunas vezes provado e atentado de se apoderar desta dicha çibdad, e teniendo en ella la parçialidad que tiene", si llegase a edificar las casas, "veniendo tienpos rebueltos, commo muchas vezes han venido, de la vezindad del dicho sennor marqués los vezinos desta çibdad resçebirían muchas fuerças e dapnnos en sus personas e bienes".

44 Sabemos que en I50I Pedro ocupó un regimiento en León por renuncia de su hermano Ramir (A.G.S., R.G.S., I50I-IX, f. 57), a fin de que retuviese el oficio hasta la mayoría de edad de un hijo de éste (A.G.S., R.G.S., I5OI-II, f. IOI). Probablemente se refiera a Gonzalo de Guzmán, hijo de Ramir que fue regidor en I5I4 y I5I5 (Díaz-Jiménez y Molleda, I906, p. 24). Personaje éste muy implicado también, como su padre, en las Comunidades: fue procurador de León en la Junta, y de hecho Pérez (1977) sitúa a Gonzalo de Guzmán dentro del pequeño grupo de procuradores que "se identificaba plenamente con la revolución" (p. 526), así como entre "los principales responsables de la insurrección” (p. 613).

${ }^{45}$ Pérez (I977, p. 43I) lo describe como "jefe indiscutible de la Comunidad [de León] desde el primer momento hasta el final de la rebelión” y lo sitúa entre "las grandes personalidades de la insurrección" (pp. 596-7) y como parte del "estado mayor político, militar e intelectual de la insurrección" (p. 6oI). 
CONCLUSIÓN: UNA ARQUEOLOGÍA DE LA IDENTIDAD URBANA POPULAR

¿De dónde proviene esta conciencia temerosa acerca de la ciudad vulnerable? Para responder esa pregunta debemos retomar los interrogantes que nos planteaba la queja de los pecheros leoneses de I490, articulada en torno a la obsesión con el enemigo nobiliario y la idea de una libertad inherente a la condición de vecino, y abordar por fin la historia de esa identidad urbana soterrada y aparentemente contrapuesta al orgullo oligárquico. Reconstruirla requiere de una labor arqueológica que nos remite a los propios orígenes de la comunidad urbana en los siglos XI-XIII, cuando ésta surge como un colectivo humano que se define por gozar de un estatuto jurídico privilegiado.

En efecto, quizá nos hemos acostumbrado demasiado estos últimos años a abordar la relación de los privilegios con la identidad urbana en clave de esa "honra cívica" promovida por las oligarquías a fines de la Edad Media, ${ }^{46}$ pero convendría no olvidar la vieja lección de los historiadores institucionalistas: en origen los privilegios son, sobre todo, ventajas muy reales, concretas y prácticas (Gautier-Dalché, 1979, pp. 17I-I75). ${ }^{47}$ Así, si acordamos con Erik Erikson que la identidad consiste en responder a la pregunta “¿quién soy?” (Montero Málaga, 20I2b, p. I24), el vecino de una comunidad urbana privilegiada de la época foral podría ofrecer, en un sentido muy primario, respuestas como: "yo soy aquella que no puede ser obligada a amasar el pan del rey” (Fuero de León, precepto no XXXVIII), ${ }^{8}$ "yo soy aquel que no debe pagar ningún portazgo desde la mar has-

46 "El cofre donde se guarda la parte más valiosa de los archivos: los privilegios de la ciudad, confirmación de derechos consuetudinarios, y derechos y privilegios arrancados a los príncipes, un "tesoro" de un valor incalculable para la identidad urbana" (Boucheron, Menjot y Boone 20Io, p. 238); "Lidentification des habitants des villes avec un régime juridique propre qui enregistre leurs privilèges est associée, en premier lieu, à la création d'une mémoire de la ville qui se manifeste par l'élaboration de chroniques qui essaient non seulement d'expliquer l'origine des privilèges que les oligarchies urbaines avaient reçus dans le passé, mais aussi de justifier leur rélation privilégiée avec la Couronne et leur position prépondérante au sein des institutions municipales crées à partir des privilèges reçus" (Díaz de Durana Ortiz de Urbina y Dacosta Martínez, 20I4, p. 136).

47 Lo señala para las polas asturianas el profesor Ruiz de la Peńa: "las exenciones y privilegios vecinales tuvieron una considerable importancia como factor de elevación social, jurídica y económica de los pobladores en relación con la situación en que se encontraban antes del otorgamiento de los instrumentos fundacionales de los nuevos núcleos urbanos" (Ruiz de la Peńa Solar, I98I, p. I8I).

${ }^{48}$ Rodríguez (I981, doc. $n^{\circ}$ 2, pp. 22-23). 
ta León" (Fuero de Oviedo, precepto $\left.\mathrm{n}^{\circ} 43\right)^{49}$ o "yo soy aquel a quien si mutilas perderás la mano" (Fuero de Llanes, precepto no 3 )..$^{50}$

Ese tipo de experiencia identitaria ${ }^{5 \mathrm{I}}$ puede haber sido el caldo de cultivo de una forma de identidad urbana basada, en primer lugar, en la conciencia de pertenecer a una comunidad cuyos privilegios la diferencian de su entorno: de ahí la forja de la idea de una especificidad sociopolítica urbana fundada en la noción de libertad. Ahora bien, esos vecinos de la primera época hubieron de ser forzosamente conscientes de que su comunidad recién constituida era, ante todo, una construcción social y, como tal, frágil y sometida a la permanente negociación de sus características. Esa idea de la especial vulnerabilidad de la ciudad, unida a su concepción como un espacio de libertad diferenciado radicalmente del mundo que lo rodea, pudo derivar fácilmente en el temor a ese entorno, cuya oposición con la imagen que los miembros de la comunidad urbana se hacen de la misma lleva a concebirlo como un medio bárbaro, caótico y criminal que se percibe como una amenaza. ${ }^{52}$ Miedo por tanto de la colectividad urbana a su entorno, y sobre todo a la figura del noble, arquetipo de ese mundo exterior que representa la posibilidad de abolir su condición privilegiada.

Ese temor originario que podemos postular para la etapa foral podría haber recibido un respaldo más institucional a través del fenómeno de las Hermandades de los siglos XIII-XIV, cuando encontramos ya un discurso antinobiliario plenamente formalizado, en el cual los grandes señores y los pequeños malfechores son presentados como una suerte de agentes del caos que funcionan como antagonistas de la comunidad urbana..$^{53}$ Pero si esa identidad urbana conformada en época antigua en torno a las nociones comunitarias de libertad y privilegio pudo servir a los intereses de las élites concejiles todavía en la época de las Hermandades, la consolidación de los sistemas de concejo cerrado, con su énfasis en la oligar-

${ }^{49}$ Miguel Vigil (199I, doc. no I, p. I7).

so Calleja Puerta (2003, pp. 78-79).

${ }^{5 I}$ Ya Gautier-Dalché (I990, p. 9) ponía de relieve que los habitantes del núcleo urbano privilegiado "forment une communauté qui est, pour chacun d'eux, une realité vécue".

52 Son especialmente significativos los casos, como el de la puebla asturiana de Maliayo (más adelante Villaviciosa), en los que esa dicotomía se da ya desde los momentos iniciales, pues de hecho son los vecinos de la zona quienes solicitan al monarca la fundación de una villa para frenar las malfetrías (Solano Fernández-Sordo, en prensa).

${ }_{53}$ Dado que lo me interesa aquí es la consolidación de un imaginario político, no creo que sea especialmente relevante el que este discurso antinobiliario deba ser matizado en cuanto a su efectividad real, o que las élites concejiles lo hayan utilizado para sus propios fines, tal y como concluye la investigación reciente sobre el fenómeno (Asenjo González, I997; González Mínguez, I991 y I992; Mínguez Fernández, 1990). 
quización, patrimonialización y profesionalización del poder, acabó por hacer necesario construir un nuevo tipo de discurso sobre lo urbano más adecuado para legitimar la nueva forma de dominación. Fue a partir de entonces cuando las oligarquías del Regimiento fueron promoviendo un nuevo tipo de identidad urbana basada en esa "honra cívica" que concibe a la ciudad como una entidad bella, armónica y estática, a la vez que iba quedando soterrado el viejo discurso comunitario, cuyo énfasis antinobiliario carecía de sentido en un contexto en el que los propios dirigentes urbanos se entregaban con verdadera fruición al camino del ennoblecimiento.

Soterrado, mas no olvidado. Los grupos populares de las ciudades castellanas, particularmente los pecheros, parecen haber mantenido viva la tradición comunitaria y asamblearista de la etapa plenomedieval (Monsalvo Antón, 2004). Probablemente en conexión con ello, el viejo discurso del miedo antinobiliario permaneció como un referente identitario latente en la cultura política urbana, cada vez más dotado eso sí de un sabor netamente popular a medida que avanzaba el siglo xv, y que acabará por estallar sonoramente durante el episodio de las Comunidades.

BIBLIOGRAFÍA

Álvarez Carballo, M., 20Io: "El impulso constructivo del regimiento de Llanes durante el siglo xvi", Liño. Revista Anual de Historia del Arte, I6, pp. IO-I9.

_- 20I3: "Trifulcas, agresiones y otras rivalidades políticas. Incendio y reconstrucción de la villa de Llanes", Roda da Fortuna. Revista Eletrônica sobre Antiguidade e Medievo, 2/I-I, pp. 455-469.

Álvarez Fernández, M., 2009: Oviedo a fines de la Edad Media. Morfología urbana y politica concejil, Oviedo.

—_, 2013: "Urbanismo medieval asturiano a fines de la Edad Media. Financiación y gestión del espacio público, entre la tradición medieval y la modernidad (siglos XIII-Xvi)", en M.C. Ribeiro y A. Sousa Melo (coords.), Evolução da paisagem urbana: transformação morfológica dos tecidos históricos, Braga, pp. I4I-I65.

—, 20I4: Por ser bien común e público. Experiencias politicas y praxis urbana en el Oviedo de I500, Oviedo.

Artifoni, E., 2006: "Repubblicanesimo comunale e democrazia moderna (in margine a Giovanni Villani, IX, IO: «Sapere guidare e reggere la nostra repubblica secondo la Politica»)", Bollettino Roncioniano, 6, pp. 2I-33. 
Asenjo González, M., 1997: "Ciudades y hermandades en la Corona de Castilla. Aproximación sociopolítica”, Anuario de Estudios Medievales, 27, pp. I03I46.

Aurell, J., 2005: "Le médiévisme espagnol au xx siècle: de l'isolationnisme à la modernisation", Cahiers de civilisation médiévale, I9I, pp. 20I-218.

—, 2006: "A Secret Realm: Current Trends in Spanish Medieval Studies", The Journal of English and Germanic Philology, I05.I, pp. 6I-86.

—_, 2008: "Tendencias recientes del medievalismo español”, Memoria y Civilización, II, pp. 63-IO3 [se trata de la versión castellana del artículo previo].

Barbero, A. y Vigil, M., 1978: La formación del feudalismo en la Peninsula Ibérica, Barcelona.

Barnés, H.G., 20I4: "Un científico explica por qué importan más las humanidades que la ciencia”, <http://www.elconfidencial.com/alma-corazon-vida/20I4II-I7/un-cientifico-explica-por-que-importan-mas-las-humanidades-que-laciencia_234074>.

Beaune, C. (ed.), I999: Journal d'un bourgeois de Paris de I405 à I449, Paris.

Bermejo Barrera, J.C., 2009a: La fábrica de la ignorancia. La Universidad del 'como si', Madrid.

— , 2009b: La fragilidad de los sabios y el fin del pensamiento, Madrid.

Bloch, M., I952: Introducción a la Historia, Madrid.

Bonachía Hernando, J. A., 1996: “"Más honrada que ciudad de mis reinos...»: la nobleza y el honor en el imaginario urbano (Burgos en la Baja Edad Media)”, en J. A. Bonachía Hernando (coord.), La ciudad medieval: aspectos de la vida urbana en la Castilla bajomedieval, Juan A. Bonachía Hernando, Valladolid, pp. I69-2I2.

——, 2012: "Introducción", Studia Historica. Historia Medieval, 30, pp. I923.

__ 2013: "Obras públicas, fiscalidad y bien común en las ciudades de la Castilla bajomedieval”, en J. M. Monsalvo Antón (ed.), Sociedades urbanas y culturas politicas en la Baja Edad Media castellana, 2013, pp. 17-48.

Boucheron, P., 2013: Conjurer la peur. Sienne, I338. Essai sur la force politique des images, Paris.

—- Menjot, D. y Boone, M., 2010: Historia de la Europa urbana, II: La ciudad medieval, Valencia.

Brown, P., 20II: "The Field of Late Antiquity", en D. Hernández de la Fuente (ed.), New Perspectives on Late Antiquity, Newcastle upon Tyne, pp. 6-19.

Calleja Puerta, M., 2003: El fuero de Llanes. Edición crítica, Oviedo.

Carande, R., I98I: Galería de raros atribuidos a Regino Escaro de Nogal, Madrid. 
—, 1982: Personas, libros y lugares, Madrid.

- 1989: Galería de amigos, Madrid.

Catedráticos, 1993: Catedráticos en la Academia. Académicos en la Universidad, Madrid.

Cervantes, M. de, 2004: Don Quijote de la Mancha, Madrid.

Cienfuegos Álvarez, C., I999: Libro de acuerdos del concejo de Avilés (I479-I492). Estudio y transcripción, Oviedo.

Compagni, D., 2013: Cronica, D. Cappi (ed.), Roma.

Crouzet-Pavan, É., 2008: "Dynamiques de langages: pour une relecture du système rituel vénitien (XIII - $\mathrm{xv}^{\mathrm{e}}$ siècle)", en G. Bertrand e I. Taddei (dirs.), Le destin des rituels: faire corps dans l'espace urbain, Italie-France-Allemagne, Rome, pp. 95-II5.

Dacosta Martínez, A. F., I998: "Historiografía y bandos. Reflexiones acerca de la crítica y justificación de la violencia banderiza en su contexto", en J. R. Díaz de Durana Ortiz de Urbina (ed.), La lucha de bandos en el País Vasco: de los parientes mayores a la hidalguia universal. Guipuzcoa, de los bandos a la Provincia (siglos XIV a XVI), Bilbao, pp. I2I-I48.

Del Val Valdivieso, M. I., 2006: "La identidad urbana al final de la Edad Media”, Anales de Historia Medieval de la Europa Atlántica, I, pp. 5-28.

Delumeau, J., 1989: El miedo en Occidente (siglos XIV-XVIII): una ciudad sitiada, Madrid.

Díaz de Durana Ortiz de Urbina, J.R., 2008: Pasión por la Edad Media. Entrevista a José Ángel García de Cortázar, Valencia.

—_ y Dacosta Martínez, A., 20I4: "Culture politique et identité dans les villes cantabriques à la fin du Moyen Âge”, Histoire Urbaine, 40, pp. I3I-I56.

—_ y Fernández de Larrea y Rojas, J. A., 2008: "Las relaciones contractuales de la nobleza y las élites urbanas en el País Vasco al final de la Edad Media (c. I300-I500)", en F. Foronda y A. I. Carrasco Manchado (coords.), El contrato politico en la Corona de Castilla: cultura y sociedad politicas entre los siglos X $y$ XVI, Madrid, pp. 283-32I.

— cuencias sobre los gobiernos urbanos durante la época Trastámara”, en J. M. Monsalvo Antón (ed.), Sociedades urbanas y culturas politicas en la Baja Edad Media castellana, Salamanca, pp. 49-70.

Díaz-Jiménez y Molleda, E., I906: La casa de los Guzmanes, León.

Donato, M. M. y Parenti, D. (eds.), 2013: Dal Giglio al David. Arte civica a Firenze fra Medioevo e Rinascimento. Catalogo della mostra (Firenze, I4 maggio-8 diciembre 20I3), Milano. 
Dutour, T. (ed.), 20IO: Les nobles et la ville dans l'espace francophone (XII-XVI siècles), Paris.

Enríquez Fernández, J., 1989: Colección documental del Archivo Municipal de Marquina (I355-ISI6), Donostia.

Fernández, L., I995: "El incendio de Medina del Campo (2I-VIII-I520). Un testimonio inédito", Investigaciones históricas: Época moderna y contemporánea, I3, pp. 95-106.

Fernández San Felices, J., 2008: Libro de acuerdos del concejo de Oviedo (I499). Edición y estudio diplomático, Oviedo.

Fontana, J., 1982: Historia: análisis del pasado y proyecto social, Barcelona, 1982.

- 200I: La historia de los hombres, Barcelona.

Foronda, F., 2007: "El miedo al rey». Fuentes y primeras reflexiones acerca de una emoción aristocrática en la Castilla del siglo XIv”, e-Spania, $4<\mathrm{http}$ ///espania.revues.org/2273>.

— , 2013a: "Emoción, contrato y constitución. Aproximación a los intentos (pre)constitucionalistas en la Europa de los años I460 (Sentencia de Medina del Campo, Concordia de Vilafranca del Penedès y Tratado de Saint-Maurdes-Fossés)", en F. Sabaté (dir.), Por política, terror social, Lleida, pp. I95-24I. —_, 2013b: El espanto y el miedo. Golpismo, emociones politicas y constitucionalismo en la Edad Media, Madrid.

García de Cortázar, J.Á., 2008: "Historia Social y Organización Social del Espacio", Vida y cultura: reflexiones egohistóricas, publicado el 2I-02-2008, Centro de Ciencias Humanas y Sociales, consultado el 23-I2-20I4, http://humanidades.cchs.csic.es/ih/seminariosih/jose_angel_garcia_de_cortazar.html.

__ 2009: "¿"Atomización»? de las investigaciones y ¿«regionalismo»? de las síntesis en Historia Medieval en Espańa: ¿búsqueda de identidades o simple disminución de escala?”, en La historia medieval hoy: percepción académica y percepción social. XXXV Semana de Estudios Medievales. Estella, 2 I a 25 de julio de 2008, Pamplona, pp. 343-380.

García Fernández, E., 2004: Gobernar la ciudad en la Edad Media: Oligarquías y élites urbanas en el País Vasco, Vitoria.

Gautier-Dalché, J., 1979: Historia urbana de León y Castilla en la Edad Media (siglos IX-XIII), Madrid.

_- I990: "La ville hispanique au Moyen Âge", en Concejos y ciudades en la Edad Media Hispánica. II Congreso de Estudios Medievales, Madrid, pp. 7-20.

González González, R., 20I4: "Ese persistente apocalipsis. Guerra e identidad urbana en el Journal d'un bourgeois de Paris", Roda da Fortuna. Revista Eletrônica sobre Antiguidade e Medievo, 3/I-I, pp. 332-358. 
—_ en prensa: "Vida, industria y tribulaciones de Juan de Oviedo, Recaudador Mayor de Asturias (c. I406-I494)".

González Mínguez, C., I99I y I992: "Aproximación al estudio del «movimiento hermandino" en Castilla y León”, Medievalismo, I y 2, pp. 35-55 y pp. 2960 .

Jara Fuente, J. A., 20I0: "Percepción de «sí», percepción del «otro»: la construcción de identidades políticas urbanas en Castilla (el concejo de Cuenca en el siglo Xv)", Anuario de Estudios Medievales, 40/I, pp. 75-92.

__ 20Ira: "Marcos de contestación y constitución urbana: la construcción de espacios de participación política en el concejo de Cuenca (siglo xv)", Cahiers d'Études Hispaniques Médiévales, 34, pp. 4I-54.

— identidad", Hispania. Revista Española de Historia, 238, pp. 315-324.

__ 2013a: "Disciplinando las relaciones políticas: ciudad y nobleza en el siglo Xv", en J. M. Monsalvo Antón (ed.), Sociedades urbanas y culturas políticas en la Baja Edad Media castellana, Salamanca, pp. I23-I42.

—_, 20I3b: "Çercada de muchos contrarios». Didáctica de las relaciones políticas ciudad-nobleza en la Cuenca del siglo xv", Edad Media. Revista de Historia, I4, pp. I05-I27.

—_ (dir.), 2013c: Ante su identidad. La ciudad hispánica en la Baja Edad Media, Cuenca.

Lacarra, M. J. y Cacho Blecua, J. M., 20I2: Historia de la literatura española, I. Entre oralidad y escritura: la Edad Media, Barcelona.

Ladero Quesada, M. Á., 20II: "La primera madurez de las ciencias históricas en España. 1900-1936", Revista Portuguesa de História, 42, pp. I49-173.

Lecuppre-Desjardin, É., 2004: La ville des cérémonies. Essai sur la communication politique dans les anciens Pays-Bas bourguignons, Turnhout.

y Van Bruaene, A. L. (eds.), 2005: Emotions in the Heart of the City (I4thI6th century), Turnhout.

Linehan, P., 1993: History and the Historians of Medieval Spain, Oxford.

Majo Tomé, B., 20I2: "Control de la actividad cotidiana y preservación de la paz social en Valladolid a fines de la Edad Media y principios de la Edad Moderna”, en B. Arízaga Bolumburu et alii (eds.), Mundos medievales: espacios, sociedades y poder. Homenaje al Profesor José Ángel García de Cortázar y Ruiz de Aguirre, Santander, vol. II, pp. I549-1560.

_- 2013: "La violencia como expresión de un conflicto no resuelto: tensiones y reyertas en Valladolid a fines de la Edad Media", Roda da Fortuna. Revista Eletrônica sobre Antiguidade e Medievo, 2/I-I, pp. 432-454. 
Martín Duque, Á. J., I999: "Las «Semanas de Estella» y el medievalismo hispanico. Un ensayo de "egohistoria»", en La historia medieval en España: un balance historiográfico (1968-1998). XXV Semana de Estudios Medievales. Estella, I4 a I8 de julio de 1998, Pamplona, pp. 23-50.

Martín Fuertes, J. A., 1987: El concejo de Astorga (siglos XIII-XVI), León.

Miguel Vigil, C., I99I: Colección Histórico-Diplomática del Ayuntamiento de Oviedo, Oviedo (facsímil de la edición de i889).

Mínguez Fernández, J. M., 1990: "Las hermandades generales de los concejos en la Corona de Castilla (objetivos, estructura interna y contradicciones en sus manifestaciones iniciales), en Concejos y ciudades en la Edad Media Hispánica. II Congreso de Estudios Medievales, Madrid, pp. 537-567.

Mitre Fernández, E., 20II: "Una ciudad acosada en la primera mitad del siglo Xv. La capital de Francia vista por Un burgués de Paris", Talia dixit, 6, pp. 6I-84. Monet, P., 20I0: "Pour en finir avec la religion civique?", Histoire Urbaine, 27, pp. IO7-I2O.

Monsalvo Antón, J. M., 2003: "Gobierno municipal, poderes urbanos y toma de decisiones en los concejos castellanos bajomedievales (consideraciones a partir de concejos salmantinos y abulenses)", en Las sociedades urbanas en la España medieval. XXIX Semana de Estudios Medievales. Estella, Is a I9 de julio de 2002, Pamplona, pp. 409-488.

—_, 2004: "«Ayuntados a concejo». Acerca del componente comunitario en los poderes locales castellano-leoneses durante la Edad Media”, en F. Sabaté i Curull y J. Farré (coords.), El poder a l'Edat Mitjana, Lleida, pp. 209-29I.

Montero Málaga, A. I., 20I2a: El linaje de los Velasco y la ciudad de Burgos (I3791474). Identidad y poder politico, Madrid.

__ 20I2b: "Identidad e identidades: la identidad política en la historia urbana medieval. Balance historiográfico y perspectivas de análisis", Estudios Medievales Hispánicos, I, pp. I2I-I42.

Morán, G., 1999: “¿Cuál fue nuestro último debate intelectual?”, Limbo, 7, pp. 55-64. Muir, E., 198r: Civic Ritual in Renaissance Venice, Princeton.

Navarro, G., 2008: “¿Quién es quién en el medievalismo español?”, Imago Temporis. Medium Aevum, 2, pp. 299-308.

Nieto Soria, J. M., 2000-2002: "Fragmentos de ideología política urbana en la Castilla bajomedieval", Anales de la Universidad de Alicante. Historia Medieval, 13, pp. 6-72.

—-, 2013: "De la ira regia al poderío real absoluto: monarquía y miedo político en la corona castellano-leonesa”, en F. Sabaté (dir.), Por politica, terror social, Lleida, pp. 245-264. 
Oliva Herrer, H.R., 20II: "«La prisión del rey»: voces subalternas e indicios de la existencia de una identidad política en la Castilla del siglo xv", Hispania. Revista Española de Historia, 238, pp. 363-388.

Pérez, J., I977: La revolución de las Comunidades de Castilla (I520-IS2I), Madrid. Peiró Martín, I. y Pasamar Alzuria, G., 2002: Diccionario Akal de Historiadores españoles contemporáneos, Madrid.

Pelaz Flores, D., 20ıо: "El Concejo en las obras públicas de la Villa de Valladolid a partir de los Libros de Actas a finales del s. Xv", en B. Arízaga Bolumburu y J. Á. Solórzano Telechea (eds.), Construir la ciudad en la Edad Media, Logroño, pp. 6оI-6ıэ.

— 20I2: "El poder de la reina a través del señorío de sus tierras. El ejemplo de Arévalo en la Baja Edad Media”, en B. Arízaga Bolumburu et alii (eds.), Mundos medievales: espacios, sociedades y poder. Homenaje al Profesor José Ángel Garcia de Cortázar y Ruiz de Aguirre, Santander, vol. II, pp. I73I-I742.

__ 20I3a: "En danno de la cosa pública e paz e sosiego de mis rregnos». Alcance y desarrollo del conflicto nobiliario en las ciudades castellanas durante el reinado de Juan II", Roda da Fortuna. Revista Eletrônica sobre Antiguidade e Medievo, 2/I-I (2013), pp. 397-4I5.

_ ciudades castellanas del siglo xv", en J. Á. Solórzano Telechea, B. Arízaga Bolumburu y A. Aguiar Andrade (eds.), Ser mujer en la ciudad medieval europea, Logrońo, pp. 289-304.

Pythian-Adams, C., 1972: "Ceremony and the Citizen: the Communal Year at Coventry, I450-1550", en P. Clark y P. Slack (eds.), Crisis and Order in English Towns, I500-1700. Essays in urban history, London, pp. 57-85.

Poloni, A., 2005: "Fisionomia sociale e identità politica dei gruppi dirigenti poplari nella seconda metà del Duecento. Spunti di riflessione su un tema classico della storiografia comunalistica italiana", Società e storia, IIo, pp. 799-82I.

—_, 2012: "Il comune di Popolo e le sue istituzioni tra Due e Trecento. Alcune riflessioni a partire dalla storiografia dell'ultimo quindicennio", Reti Medievali Rivista, I3/I, pp. I-27.

— - 20I0: Potere al popolo. Conflitti sociali e lotte politiche nell'Italia comunale del Duecento, Milano.

Rodríguez, J., 198r: Los fueros del reino de León, II: Documentos, León.

Rodríguez López, M. C., 2006: El archivo: instrumentos de descripción y consulta. Los libros de actas municipales de Astorga (Siglo XV), León.

Ruiz de la Peña Solar, J. I., I981: Las "polas» asturianas en la Edad Media. Estudio y diplomatario, Oviedo. 
— 2004: "Las ciudades de señorío eclesiástico y los conflictos por el control del gobierno local (I252-I350)", en J. I. de la Iglesia Duarte (coord.), Conflictos sociales, politicos e intelectuales en la España de los siglos XIV y XV. XIV Semana de Estudios Medievales. Nájera, del 4 al 8 de agosto de 2003, Logroño, pp II3-I45.

_ la delincuencia en la Asturias Medieval (siglos XII-XIv)", Clio \& Crimen, 3, pp. 49-67.

_ 2009 : "Cuatro «acreedores preferentes» del medievalismo español: Eduardo de Hinojosa, Ramón Menéndez Pidal, Manuel Gómez-Moreno y Claudio Sánchez-Albornoz", en La historia medieval hoy: percepción académica y percepción social. XXXV Semana de Estudios Medievales. Estella, 2 a a 25 de julio de 2008, Pamplona, pp. 193-230.

—— y Beltrán Suárez, S., 2orI: "Señoríos compartidos, señoríos conflictivos. Los obispos y el concejo de Oviedo en la Edad Media”, en G. Cavero Domínguez (coord.), Iglesia y ciudad. Espacio y poder (siglos VIII-XIII), León, pp. I37-I77.

Ruiz-Domènec, J. E., 20I4: "Un pedazo de la vida: los senderos de un medievalista europeo para el siglo XxI”, Historia Crítica, 54, pp. I25-I4I.

Santamarta Luengos, J.M., I993: Señorio y relaciones de poder en León en la Baja Edad Media (Concejo y Cabildo Catedral en el siglo XV), León.

Sanz Fuentes, M.J., Álvarez Castrillón, J. A. y Calleja Puerta, M., 2orr: Colección diplomática del concejo de Avilés en la Edad Media (II55-I498), Avilés.

Signori, G., 20I0: "Religion civique - Patriotisme urbain. Concepts au banc d'essai", Histoire Urbaine, 27, pp. 9-20.

Skinner, Q., 1995: "Las ciudades-república italianas", en J. Dunn (dir.), Democracia: el viaje inacabado (508 a.C.-1993), Barcelona, pp. 70-82.

Solano Fernández-Sordo, Á., en prensa: " "Algunas cosas que son neçesarias para la buena governaçión de dicha villa e conçejo». Poder concejil, gobierno urbano y conflicto social en Villaviciosa a fines de la Edad Media”.

Solórzano Telechea, J. Á., I999: Colección Documental de la Villa Medieval de Santander en el Archivo General de Simancas (I326-I498), Santander.

__ 2007: "Linaje, comunidad y poder: desarrollo y consolidación de identidades urbanas contrapuestas en la Castilla bajomedieval”, en Familia y sociedad en la Edad Media (siglos XII-XV), Zaragoza, pp. 7I-93.

Uría Ríu, J., 2008: "El asedio de Oviedo por Enrique de Trastámara en I352", en Obra completa, III: Estudios sobre Oviedo, Oviedo, pp. 239-244.

—_, 20I0a: "Respuesta de los Reyes Católicos a las peticiones de la Junta General del Principado de Asturias en el año I475", en Obra completa, IV: Estudios medievales, Oviedo, pp. 305-345. 
_- 20Iob: "Apuntes para la historia de Llanes", en Obra completa, IV: Estudios medievales, Oviedo, pp. 687-723.

Ventrone, P., 1988: "Le forme dello spettacolo toscano nel Trecento: tra rituale civico e cerimoniale festivo", en S. Gensini (ed.), La Toscana nel secolo XIV. Caratteri di una civiltà regionale. Atti del I Convegno del Centro di Studi sulla Civiltà del Tardo Medioevo (San Miniato, I-5 ottobre 1986), Pisa, pp. 497-517.

_ 2007 : "La festa di San Giovanni: costruzione di un'identità civica fra rituale e spettacolo (secoli XIV-XvI)", Annali di Storia di Firenze, 2, pp. 49-76.

_ , 2013: "Simbologia e funzione delle feste identitarie in alcune città italiane fra XIII e Xv secolo", Teatro e Storia, 34, pp. 285-3IO. 